DOI: https://doi.org/10.24127/ajpm.v10i1.3256

\title{
KEMAMPUAN PEMECAHAN MASALAH GEOMETRI BERBASIS BUDAYA DITINJAU DARI GENDER DAN GAYA BELAJAR
}

\author{
Arief Budi Wicaksono $^{1 *}$, Aprilia Nurul Chasanah ${ }^{2}$, Heru Sukoco ${ }^{3}$ \\ ${ }^{1 *, 2}$ Universitas Tidar, Magelang, Indonesia \\ ${ }^{3}$ Universitas Negeri Yogyakarta, Sleman, Indonesia \\ *Corresponding author. Universitas Tidar, 56116, Magelang, Indonesia. \\ E-mail: $\quad$ ariefbudiw@untidar.ac.id ${ }^{\left.{ }^{*}\right)}$ \\ aprilianurul@untidar.ac.id $^{2)}$ \\ heru.sukoco@uny.ac.id ${ }^{3)}$
}

Received 19 November 2020; Received in revised form 05 March 2021; Accepted 31 March 2021

\begin{abstract}
Abstrak
Tujuan penelitian ini adalah mendeskripsikan kemampuan pemecahan masalah geometri berbasis budaya pada mahasiswa pendidikan matematika ditinjau dari perbedaan gender dan gaya belajar David Kolb. Jenis penelitian ini adalah deskriptif kualitatif dengan subjek penelitian mahasiswa Program Studi Pendidikan Matematika Universitas Tidar pada mata kuliah Geometri Ruang sebanyak delapan mahasiswa (gaya belajar diverging, assimilating, converging, dan accommodating) yang masing-masing gaya belajar terdiri dari laki-laki dan perempuan. Instrumen dalam penelitian ini adalah angket tes gaya belajar David Kolb, soal tes kemampuan pemecahan masalah geometri berbasis budaya dan pedoman wawancara. Data dianalisis secara kualitatif kemudian dibandingkan hasil tes tertulis dan wawancara. Hasil penelitian menunjukkan bahwa mahasiswa dengan gaya belajar diverging, subjek laki-laki berada pada kategori kurang dan subjek perempuan berada pada kategori cukup dalam pemecahan masalah. Kemampuan mahasiswa dengan gaya belajar assimilating, baik subjek laki-laki maupun perempuan berada pada kategori cukup dalam pemecahan masalah. Kemampuan mahasiswa dengan gaya belajar converging, baik subjek laki-laki maupun perempuan berada pada kategori cukup dalam pemecahan masalah. Kemampuan mahasiswa dengan gaya belajar accommodating, baik subjek laki-laki maupun perempuan berada pada kategori cukup dalam pemecahan masalah.
\end{abstract}

Kata kunci: Budaya; gaya belajar; gender; geometri; pemecahan masalah.

\begin{abstract}
The purpose of this study is to describe the culturally-based geometry problem-solving ability of mathematics education students based on gender differences and David Kolb's learning style. This type of research is qualitatively descriptive with the study subjects of Mathematics Education Study Program Universitas Tidar on the Space Geometry of eight students (diverging, assimilating, converging, and accommodating learning styles) whose respective learning styles consist of male and female. The instrument in this study is David Kolb's study style test questionnaire, a culturally-based geometry problem-solving ability test, and interview guidelines. Data is qualitatively analyzed and then compared the results of test and interview. The results showed that students with diverging learning styles, male subjects were in the poor category, and female subjects were in fair categories in problem-solving. The ability of students with an assimilating learning style, both male and female subjects is in the category of fair in problem-solving. The ability of students with a converging learning style, both male and female subjects is in fair categories in problem-solving. The ability of students with accommodating learning styles, both male and female subjects is in the category of fair in problem-solving.
\end{abstract}

Keywords: Culture; gender; geometry; learning style; problem solving. 
DOI: https://doi.org/10.24127/ajpm.v10i1.3256

\section{PENDAHULUAN}

Matematika merupakan salah satu cabang ilmu pengetahuan yang memegang peranan penting. Matematika sangat diperlukan dalam menyelesaikan masalah yang berkaitan dengan kehidupan sehari-hari dan merupakan sarana pemecahan masalah yang baik. (NCTM, 2000) menetapkan lima standar kemampuan matematis, yaitu pemecahan masalah (problem solving), kemampuan komunikasi (communication), kemampuan koneksi (connection), kemampuan penalaran (reasoning), dan kemampuan representasi (representation). Berdasarkan hal tersebut kemampuan pemecahan masalah (problem solving) harus dikuasai oleh mahasiswa dalam pembelajaran matematika. Kemampuan pemecahan masalah digunakan untuk menyelesaikan masalah dalam matematika sehingga dengan adanya pemecahan masalah membuat matematika tidak kehilangan maknanya, sebab konsep dan prinsip matematika akan lebih bermakna jika diterapkan dalam suatu permasalahan.

Menurut (Mawaddah \& Anisah, 2015), pemecahan masalah adalah suatu proses berpikir seseorang untuk menentukan apa yang harus dilakukan untuk menyelesaikan suatu masalah yang menuntut seseorang untuk mengkoordinasikan pengalaman, pengetahuan, pemahaman yang dimiliki. (Chao, Tzeng, \& Po, 2017) mengungkapkan bahwa pemecahan masalah adalah pemrosesan menemukan jawaban oleh individu dengan menerapkan pengetahuan dan keterampilan mereka yang sudah ada ke alat dan aplikasi untuk memenuhi persyaratan situasi baru karena situasi baru dan tidak dikenal, penyelesaian masalah dianggap sebagai model aktivitas mental yang tinggi. Jadi, dapat disimpulkan bahwa kemampuan pemecahan masalah adalah suatu proses berpikir untuk menyelesaikan suatu permasalahan dengan pengetahuan dan keterampilan yang sudah ada untuk mencapai tujuan serta merupakan model penemuan solusi melalui langkahlangkah pemecahan masalah. (Polya, 2014) mengungkapkan empat langkah pemecahan masalah yaitu memahami masalah (understand the problem), merencanakan pemecahan (devise a plan), melaksanakan rencana (carry out the plan), dan melihat kembali (looking back). Pada setiap langkah-langkah pemecahan masalah akan masuk dalam indikator pemecahan masalah. Menurut (NCTM, 2000) indikator pemecahan masalah yaitu 1) mengembangkan pengetahuan matematika baru melalui pemecahan masalah, 2) memecahkan masalah matematika dalam berbagai konteks, 3) menerapkan strategi yang tepat untuk memecahkan masalah, dan 4) merefleksikan proses pemecahan masalah.

Pemecahan masalah sangat penting dalam pembelajaran matematika. Salah satu faktor yang mempengaruhi perbedaan tingkat kemampuan pemecahan masalah adalah gaya belajar. Menurut Felder dan Silverman, seperti yang dikutip oleh (Middleton, Ricks, Wright, \& Grant, 2013), gaya belajar adalah pilihan bagaimana individu menerima dan memproses informasi. Menurut Hall seperti yang dikemukakan oleh (Ma \& Ma, 2014), gaya belajar merupakan cara seseorang mulai berkonsentrasi, memproses, mengingat informasi akademik yang baru dan sulit. Gaya belajar merupakan metode yang digunakan oleh individu untuk memfokuskan dan menguasai informasi baru (Sengodan \& Iksan, 2012). 
(Kolb \& Kolb, 2017) membagi gaya belajar menjadi empat, antara lain (1) Diverging yaitu kombinasi elemen Pengalaman Konkrit dan Observasi Reflektif. Individu dengan gaya belajar ini mampu melihat situasi konkrit dari beragam perspektif; (2) Assimilating yaitu kombinasi Konseptualisasi Abstrak dan Observasi Reflektif. Individu ini terampil dalam mengolah banyak informasi serta menempatkannya ke dalam bentuk yang pasti dan logis; (3) Converging yaitu kombinasi Konseptualisasi Abstrak dan Eksperimen Aktif. Individu ini paling baik dalam menemukan kegunaan praktis dari ide dan teori; dan (4) Accommodating yaitu kombinasi Pengalaman Konkrit dan Eksperimentasi Aktif. Individu ini memiliki keunggulan untuk belajar dari pengalaman langsung. ( Bire, Geradus, \& Bire, 2014) berpendapat bahwa cara seseorang menyerap informasi, mengolahnya, dan memanifestasikan dalam wujud nyata perilaku hidupnya disebut dengan gaya/tipe belajar. Setiap mahasiswa memiliki gaya belajar yang berbeda-beda, apalagi terdapat mahasiswa yang bermacam-macam karakteristik dan gender, tetapi mungkin juga ada yang memiliki gaya belajar yang sejenis. Dengan adanya gaya belajar yang berbeda ini mengakibatkan cara memahami dan menyerap informasi setiap mahasiswa dalam pembelajaran berbeda sehingga kemampuan pemecahan masalah yang dimilikinya juga berbeda.

(Budiarto \& Artiono, 2019) mengungkapkan eksplorasi terhadap geometri dapat mengembangkan keterampilan dalam memecahkan masalah. Penalaran ruangan adalah bentuk pemecahan masalah yang terpenting, dan seperti tercantum dalam kurikulum di Indonesia, pemecahan masalah merupakan salah satu alasan utama dalam mempelajari matematika. Suatu permasalahan matematika akan mudah dipecahkan dengan menggunakan bahasa gambar geometri, dan merupakan sebagian dari penyelesaian. Masalah geometri dapat disajikan dengan memberikan soal yang berkaitan dengan masalah kontekstual salah satunya dengan mengangkat tema budaya. Soal tes kemampuan pemecahan masalah konteks budaya dalam penelitian ini adalah soal geometri dengan tema budaya daerah Jawa Tengah dan Daerah Istimewa Yogyakarta yang memiliki keragaman disetiap aspek budaya. Penyajian soal konteks budaya tersebut dimaksudkan untuk mengenalkan kepada mahasiswa bahwa budaya daerah yang ada di sekitar mereka terdapat unsur matematika dan mampu memecahkan masalah matematika yang berkaitan dengan budaya mereka. Berdasarkan uraian tersebut, dilakukan penelitian tentang kemampuan pemecahan masalah geometri berbasis budaya pada mahasiswa Pendidikan Matematika di Universitas Tidar ditinjau dari perbedaan gender dan gaya belajar David Kolb.

\section{METODE PENELITIAN}

Jenis penelitian yang digunakan dalam penelitian ini adalah deskriptif kualitatif. Subjek penelitian adalah mahasiswa semester II Program Studi Pendidikan Matematika Universitas Tidar sebanyak 8 mahasiswa yang terdiri dari gender laki-laki dan perempuan. Pemilihan subjek secara purposive sampling dengan kriteria subjek memiliki gaya belajar diverging, assimilating, converging, dan accommodating.

Instrumen dalam penelitian ini adalah angket tes gaya belajar David 
DOI: https://doi.org/10.24127/ajpm.v10i1.3256

Kolb, soal tes kemampuan pemecahan masalah geometri berbasis budaya dan pedoman wawancara. Metode pengumpulan data penelitian yaitu 1) metode angket, dilakukan untuk mengetahui gaya belajar siswa dan gender sesuai dengan gaya belajar David Kolb; 2) metode tes, dilakukan secara tertulis kepada subyek penelitian sesuai dengan indikator kemampuan pemecahan masalah matematika menurut Polya; dan 3) metode wawancara, digunakan untuk mengetahui kemampuan pemecahan masalah matematika.
Data tes tertulis dianalisis berdasarkan indikator kemampuan pemecahan masalah, sedangkan data wawancara dianalisis sesuai dengan teknik analisis yang diungkapkan oleh (Miles \& Huberman, 1994) yaitu (1) reduksi data, (2) penyajian data, dan (3) penarikan kesimpulan. Hasil analisis data tes tertulis dan wawancara kemudian dibandingkan dan divalidasi untuk ditarik kesimpulan. Indikator dan pedoman penilaian kemampuan pemecahan masalah disajikan pada Tabel 1.

Tabel 1. Indikator dan pedoman penilaian kemampuan pemecahan masalah

\begin{tabular}{|c|c|c|}
\hline $\begin{array}{l}\text { Tahapan Pemecahan } \\
\text { Masalah (Indikator) }\end{array}$ & Kategori & Deskripsi \\
\hline \multirow[t]{3}{*}{ Memahami masalah } & Baik & $\begin{array}{l}\text { Mampu memahami masalah secara menyeluruh, yaitu } \\
\text { mengungkapkan informasi yang diketahui dan } \\
\text { pertanyaan yang diajukan dari masalah yang } \\
\text { diberikan }\end{array}$ \\
\hline & Cukup & $\begin{array}{l}\text { Salah mengintepretasikan sebagian masalah atau tidak } \\
\text { memahami masalah secara keseluruhan }\end{array}$ \\
\hline & Kurang & $\begin{array}{l}\text { Salah mengintepretasikan masalah secara lengkap } \\
\text { atau tidak memahami masalah secara utuh }\end{array}$ \\
\hline \multirow[t]{3}{*}{$\begin{array}{l}\text { Menyusun rencana } \\
\text { pemecahan masalah }\end{array}$} & Baik & $\begin{array}{l}\text { Membuat langkah pemecahan masalah dengan benar } \\
\text { dan mengarah pada solusi yang benar }\end{array}$ \\
\hline & Cukup & $\begin{array}{l}\text { Membuat langkah pemecahan masalah yang dapat } \\
\text { diterapkan namun memungkinkan tidak mendapatkan } \\
\text { hasil yang sesuai/mendapatkan hasil yang salah }\end{array}$ \\
\hline & Kurang & $\begin{array}{l}\text { Tidak membuat langkah pemecahan masalah yang } \\
\text { relevan }\end{array}$ \\
\hline \multirow[t]{3}{*}{$\begin{array}{l}\text { Melaksanakan rencana } \\
\text { pemecahan masalah }\end{array}$} & Baik & $\begin{array}{l}\text { Menyelesaikan seluruh masalah dan memperoleh } \\
\text { jawaban yang benar }\end{array}$ \\
\hline & Cukup & $\begin{array}{l}\text { Menyelesaikan sebagian masalah dan memperoleh } \\
\text { jawaban yang benar }\end{array}$ \\
\hline & Kurang & $\begin{array}{l}\text { Tidak melakukan penyelesaian masalah atau } \\
\text { menyelesaikan sebagian atau seluruh masalah namun } \\
\text { mendapatkan hasil yang salah }\end{array}$ \\
\hline \multirow{3}{*}{$\begin{array}{l}\text { Mengecek } \\
\text { hasil } \\
\text { masalah }\end{array}$} & Baik & $\begin{array}{l}\text { Memeriksa hasil pemecahan masalah dan menuliskan } \\
\text { kesimpulan dengan tepat }\end{array}$ \\
\hline & Cukup & $\begin{array}{l}\text { Memeriksa hasil pemecahan masalah dan/atau } \\
\text { menuliskan kesimpulan dengan kurang tepat/ tidak } \\
\text { lengkap }\end{array}$ \\
\hline & Kurang & $\begin{array}{l}\text { Tidak memeriksa hasil pemecahan masalah dan tidak } \\
\text { menuliskan kesimpulan }\end{array}$ \\
\hline
\end{tabular}


DOI: https://doi.org/10.24127/ajpm.v10i1.3256

\section{HASIL DAN PEMBAHASAN}

Hasil yang diperoleh dalam penelitian ini adalah kemampuan mahasiswa pendidikan matematika dalam memecahkan masalah geometri berbasis budaya ditinjau dari perbedaan gender dan gaya belajar David Kolb. Berikut disajikan hasil dokumentasi tertulis dan hasil pengisian angket gaya belajar dari subjek penelitian serta kategorisasi kemampuan pemecahan masalah mereka.

\section{Mahasiswa dengan Gaya Belajar Diverging}

Pada mahasiswa dengan gaya belajar diverging, diambil subjek lakilaki dan perempuan dengan menganalisis permasalahan geometri pada soal nomor 2. Adapun jawaban dari subjek laki-laki dengan gaya belajar diverging disajikan pada Gambar 1.

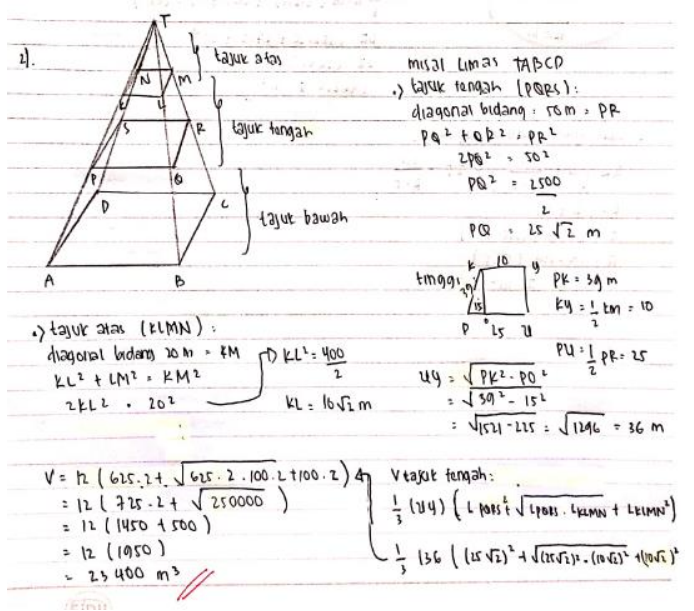

Gambar 1. Jawaban subjek laki-laki dengan gaya belajar diverging

Berdasarkan Gambar 1 yaitu hasil tertulis soal pemecahan masalah pada subjek laki-laki dengan gaya belajar diverging, maka dapat dideskripsikan subjek tersebut kurang pada tahapan memahami masalah karena tidak mampu memahami masalah secara utuh, terlihat bahwa subjek tidak menuliskan informasi yang diketahui dan ditanyakan dari pertanyaan yang diajukan dari masalah yang diberikan. Subjek sudah baik dalam menyusun rencana pemecahan masalah dan melaksanakan rencana pemecahan masalah. Subjek tersebut juga kurang pada tahapan mengecek kembali hasil pemecahan masalah karena tidak menuliskan kesimpulan dari jawaban yang diperoleh. Hal ini juga sejalan dengan (Riau \& Junaedi, 2016) yang menyatakan bahwa gaya belajar diverging saat mengerjakan tes kemampuan pemecahan masalah tidak dapat menunjukkan langkah-langkah penyelesainnya pada tahap pengecekan kembali. Selain itu subjek dengan gaya belajar diverging lebih cepat bosan jika tidak memahami masalah dan berkreasi. (Jalinus, et al., 2020).

Selanjutnya, ditampilkan jawaban dari subjek perempuan dengan gaya belajar diverging disajikan pada Gambar 2.

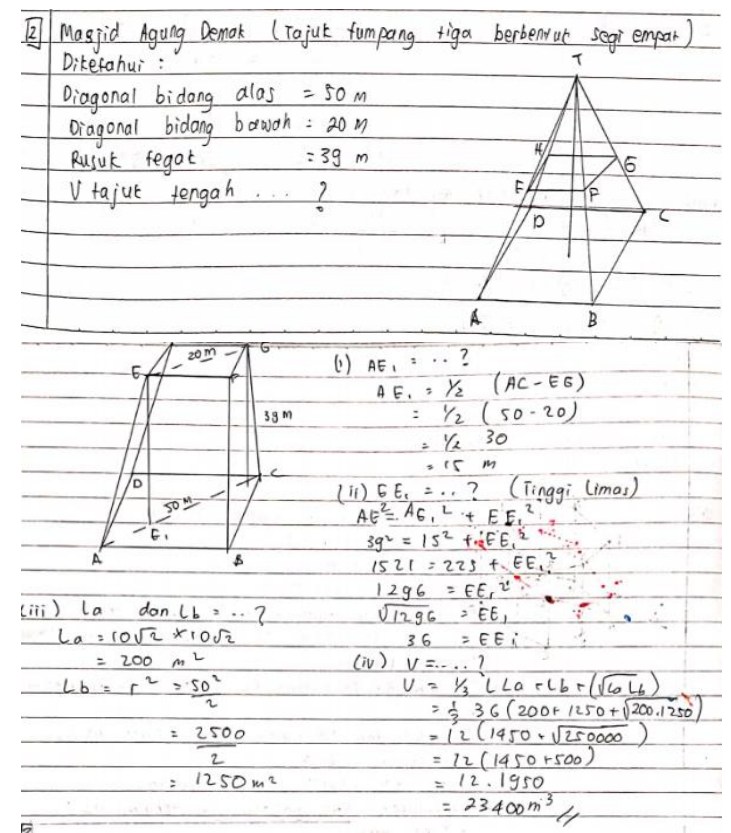

Gambar 2. Jawaban subjek perempuan dengan gaya belajar diverging 
DOI: https://doi.org/10.24127/ajpm.v10i1.3256

Berdasarkan hasil tertulis soal pemecahan masalah pada subjek perempuan dengan gaya belajar diverging yang ditampilkan pada Gambar 2, dapat dideskripsikan bahwa subjek tersebut sudah baik pada tahapan memahami masalah, menyusun rencana pemecahan masalah, dan melaksanakan rencana pemecahan masalah. Subjek perempuan mampu menuliskan yang diketahui dan ditanyakan pada soal, dapat menyusun rencana penyelesaian soal dan melaksanakan rencana penyelesaian soal tersebut dengan baik. Namun, tahapan mengecek kembali hasil pemecahan masalah subjek tersebut masih kurang karena tidak menuliskan kesimpulan dari jawaban yang diperoleh.

Berdasarkan pemaparan di atas, maka dapat disimpulkan hasil tertulis subjek laki-laki dan perempuan dengan gaya belajar diverging dalam Tabel 2 .

Tabel 2. Rangkuman mahasiswa dengan gaya belajar diverging

\begin{tabular}{|c|c|c|}
\hline \multirow[b]{2}{*}{ Tahapan } & \multicolumn{2}{|c|}{ Kategori } \\
\hline & $\begin{array}{l}\text { Laki- } \\
\text { laki }\end{array}$ & Perempuan \\
\hline $\begin{array}{l}\text { Memahami } \\
\text { masalah }\end{array}$ & Kurang & Baik \\
\hline $\begin{array}{l}\text { Menyusun } \\
\text { rencana } \\
\text { pemecahan } \\
\text { masalah }\end{array}$ & Baik & Baik \\
\hline $\begin{array}{l}\text { Melaksanakan } \\
\text { rencana } \\
\text { pemecahan } \\
\text { masalah }\end{array}$ & Baik & Baik \\
\hline $\begin{array}{l}\text { Mengecek } \\
\text { kembali hasil } \\
\text { pemecahan } \\
\text { masalah }\end{array}$ & Kurang & Kurang \\
\hline
\end{tabular}

Pada tahapan memahami masalah, subjek perempuan lebih baik daripada subjek laki-laki. Kedua subjek sama- sama baik pada tahapan menyusun rencana pemecahan masalah dan melaksanakan rencana pemecahan masalah. Pada tahapan mengecek kembali hasil pemecahan masalah, kedua subjek masih dalam kategori kurang.

Berdasarkan keseluruhan jawaban subjek dengan gaya belajar diverging, subjek laki-laki berada pada kategori kurang dan subjek perempuan berada pada kategori cukup. Penelitian ini relevan dengan penelitian dari (Riau \& Junaedi, 2016) yang menyatakan bahwa subjek dengan gaya belajar diverging hanya mampu menyelesaikan pada langkah merencanakan pemecahan masalah dan gagal dalam memecahkan masalah. Selain itu, (Fatkhiyyah, Winarso, \& Manfaat, 2019) yang meneliti tentang kemampuan komunikasi matematika ditinjau dari perbedaan gender menyatakan bahwa subjek dengan gaya belajar diverging memiliki kemampuan komunikasi matematika rendah (kurang).

\section{Mahasiswa dengan Gaya Belajar Assimilating}

Pada mahasiswa dengan gaya belajar assimilating, diambil subjek laki-laki dan perempuan dengan menganalisis permasalahan geometri pada soal nomor 4. Jawaban dari subjek laki-laki dengan gaya belajar assimilating disajikan pada Gambar 3.

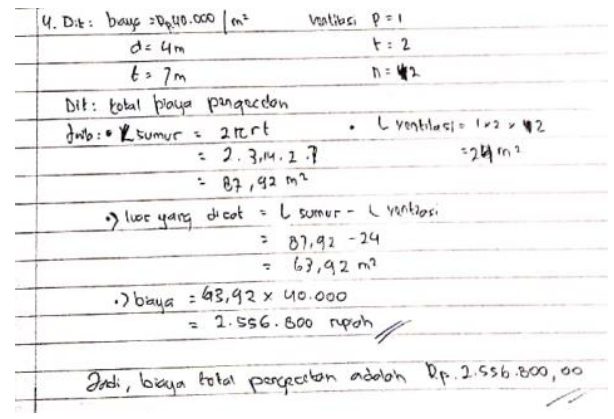

Gambar 3. Jawaban subjek laki-laki dengan gaya belajar assimilating 
DOI: https://doi.org/10.24127/ajpm.v10i1.3256

Berdasarkan Gamabr 3 yang menyajikan hasil tertulis berupa pemecahan masalah oleh subjek lakilaki dengan gaya belajar assimilating, maka dapat dideskripsikan subjek tersebut baik pada tahapan memahami masalah karena mampu memahami masalah secara utuh, terlihat bahwa subjek menuliskan informasi yang diketahui dan pertanyaan yang diajukan dari masalah yang diberikan. Kemudian subjek tersebut cukup dalam menyusun rencana pemecahan masalah dan melaksanakan rencana pemecahan masalah, subjek tersebut sudah mampu menuliskan rumus-rumus yang diperlukan dalam penyelesaian soal akan tetapi masih terdapat kesalahan dalam perhitungan. Pada tahapan mengecek kembali hasil pemecahan masalah, subjek tersebut mampu menuliskan kesimpulan dari jawaban soal akan tetapi jawabanya masih belum tepat. Jawaban subjek perempuan dengan gaya belajar assimilating dapat dilihat pada Gambar 4.

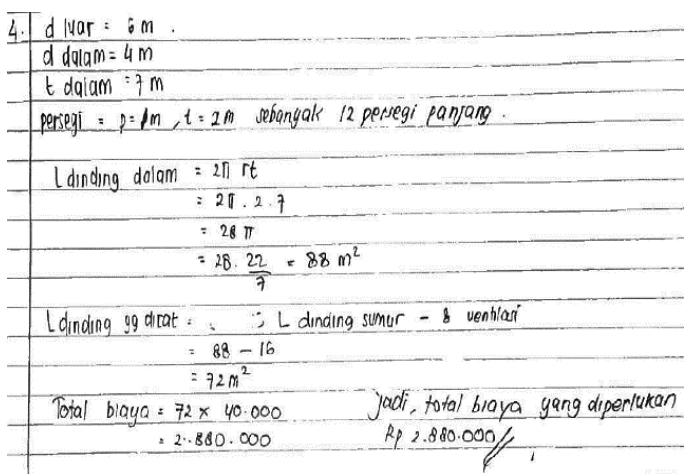

Gambar 4. Jawaban subjek perempuan dengan gaya belajar assimilating

Berdasarkan hasil tertulis soal pemecahan masalah pada subjek perempuan dengan gaya belajar assimilating, maka dapat dideskripsikan subjek tersebut cukup pada tahapan memahami masalah, terlihat bahwa subjek menuliskan informasi yang diketahui dari pertanyaan, namun tidak menuliskan permasalahan yang ditanyakan dalam soal. Kemudian subjek tersebut cukup dalam menyusun rencana pemecahan masalah dan melaksanakan rencana pemecahan masalah, subjek tersebut sudah mampu menuliskan rumus-rumus yang diperlukan dalam penyelesaian soal akan tetapi masih terdapat kekeliruan dalam perhitungan. Pada tahapan mengecek kembali hasil pemecahan masalah, subjek tersebut mampu menuliskan kesimpulan dari jawaban soal akan tetapi jawabanya masih belum tepat.

Berdasarkan pemaparan di atas, maka dapat disimpulkan hasil tertulis subjek laki-laki dan perempuan dengan gaya belajar assimilating dalam Tabel 3 .

Tabel 3. Rangkuman mahasiswa dengan gaya belajar assimilating

\begin{tabular}{|c|c|c|}
\hline \multirow[b]{2}{*}{ Tahapan } & \multicolumn{2}{|c|}{ Kategori } \\
\hline & $\begin{array}{c}\text { Laki- } \\
\text { laki }\end{array}$ & Perempuan \\
\hline $\begin{array}{l}\text { Memahami } \\
\text { masalah }\end{array}$ & Baik & Cukup \\
\hline $\begin{array}{l}\text { Menyusun } \\
\text { rencana } \\
\text { pemecahan } \\
\text { masalah }\end{array}$ & Cukup & Cukup \\
\hline $\begin{array}{l}\text { Melaksanakan } \\
\text { rencana } \\
\text { pemecahan } \\
\text { masalah }\end{array}$ & Cukup & Cukup \\
\hline $\begin{array}{l}\text { Mengecek } \\
\text { kembali hasil } \\
\text { pemecahan } \\
\text { masalah }\end{array}$ & Cukup & Cukup \\
\hline
\end{tabular}

Pada tahapan menyusun rencana pemecahan masalah, melaksanakan rencana pemecahan masalah, dan mengecek kembali hasil pemecahan masalah, subjek laki-laki dan perempuan berada pada kategori cukup. Sedangkan pada tahapan memahami 
masalah subjek laki-laki lebih baik dari subjek perempuan karena mampu menuliskan informasi yang diketahui dan pertanyaan yang diajukan dari masalah yang diberikan.

Berdasarkan keseluruhan jawaban subjek dengan gaya belajar assimilating, baik subjek laki-laki maupun perempuan berada pada kategori cukup. Subjek tersebut sudah cukup dalam memahami masalah, menyusun rencana pemecahan masalah, dan melaksanakan rencana pemecahan masalah. Penelitian ini relevan dengan penelitian dari (Riau \& Junaedi, 2016) yang menyatakan bahwa subjek dengan gaya belajar assimilating mampu pada langkah mengecek kembali tetapi tidak sempurna. Selain itu, (Fatkhiyyah, Winarso, \& Manfaat, 2019) yang meneliti kemampuan komunikasi matematika ditinjau dari perbedaan gender menyatakan bahwa subjek dengan gaya belajar assimilating memiliki kemampuan komunikasi matematika sedang (cukup).

\section{Mahasiswa dengan Gaya Belajar Converging}

Pada mahasiswa dengan gaya belajar converging, diambil subjek lakilaki dan perempuan dengan menganalisis permasalahan geometri pada soal nomor 3. Adapun jawaban dari subjek laki-laki dengan gaya belajar converging dapat dilihat pada Gambar 5.

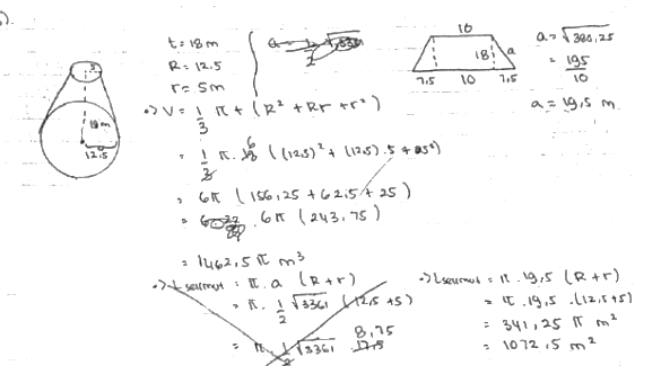

Gambar 5. Jawaban subjek laki-laki dengan gaya belajar converging
Berdasarkan hasil tertulis soal pemecahan masalah pada subjek lakilaki dengan gaya belajar converging, maka dapat dideskripsikan subjek tersebut berada di kategori cukup pada tahapan memahami masalah, terlihat bahwa subjek menuliskan informasi yang diketahui dari pertanyaan, namun tidak menuliskan permasalahan yang ditanyakan dalam soal. Subjek sudah baik dalam menyusun rencana pemecahan masalah dan melaksanakan rencana pemecahan masalah. Subjek tersebut kurang pada tahapan mengecek kembali hasil pemecahan masalah karena tidak menuliskan kesimpulan dari jawaban yang diperoleh.

Hasil selanjutnya yaitu hasil jawaban dari subjek perempuan dengan gaya belajar converging dapat dilihat pada Gambar 6.

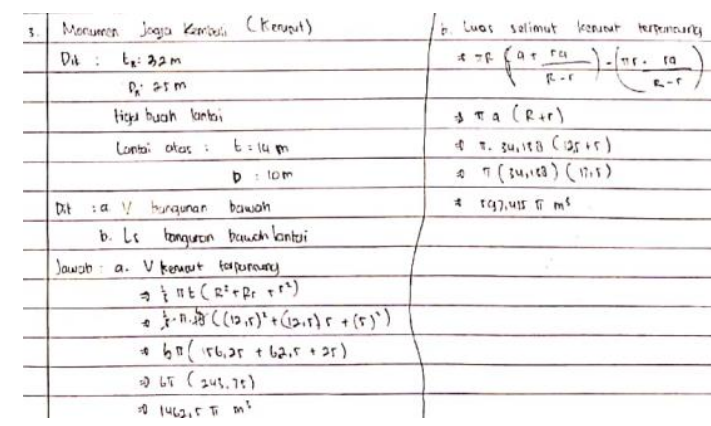

Gambar 6. Jawaban subjek perempuan dengan gaya belajar converging

Berdasarkan hasil tertulis soal pemecahan masalah pada subjek perempuan dengan gaya belajar converging. Pada tahapan memahami masalah, terlihat bahwa subjek perempuan dapat menuliskan informasi yang diketahui dan pertanyaan yang diajukan pada soal dengan benar. Pada tahapan menyusun rencana pemecahan masalah dan melaksanakan rencana pemecahan masalah berada di kategori cukup karena mampu menuliskan rumus yang diperlukan dalam penyelesaian permasalahan pada soal, namun 
perhitungannya masih belum tepat. Subjek perempuan kurang pada tahapan mengecek kembali hasil pemecahan masalah karena tidak menuliskan kesimpulan dari jawaban yang diperoleh.

Berdasarkan pemaparan di atas, maka dapat disimpulkan hasil tertulis subjek laki-laki dan perempuan dengan gaya belajar converging dalam Tabel 4 .

Tabel 4. Rangkuman mahasiswa dengan gaya belajar converging

\begin{tabular}{lll}
\hline \multirow{2}{*}{ Tahapan } & \multicolumn{2}{l}{ Kategori } \\
\cline { 2 - 3 } & $\begin{array}{l}\text { Laki- } \\
\text { laki }\end{array}$ & Perempuan \\
\hline $\begin{array}{l}\text { Memahami } \\
\text { masalah }\end{array}$ & Cukup & Baik \\
$\begin{array}{l}\text { Menyusun } \\
\text { rencana } \\
\text { pemecahan } \\
\text { masalah }\end{array}$ & Baik & Cukup \\
$\begin{array}{l}\text { Melaksanakan } \\
\text { rencana } \\
\text { pemecahan } \\
\text { masalah }\end{array}$ & Baik & Cukup \\
$\begin{array}{l}\text { Mengecek } \\
\text { kembali hasil } \\
\text { pemecahan } \\
\text { masalah }\end{array}$ & Kurang & Kurang \\
\hline
\end{tabular}

Pada tahapan memahami masalah, subjek perempuan lebih baik daripada subjek laki-laki. Pada tahapan menyusun rencana pemecahan masalah dan melaksanakan rencana pemecahan masalah, subjek laki-laki lebih baik daripada subjek perempuan. Pada tahap mengecek kembali hasil pemecahan masalah berada pada kategori kurang untuk kedua subjek karena tidak menuliskan kesimpulan dari jawaban yang diperoleh.

Berdasarkan keseluruhan jawaban subjek dengan gaya belajar converging, subjek laki-laki dan perempuan berada pada kategori cukup. Penelitian ini relevan dengan penelitian dari (Riau \& Junaedi, 2016) yang menyatakan bahwa subjek dengan gaya belajar converging mampu menyelesaikan pemecahan masalah pada langkah mengecek kembali. Selain itu, (Fatkhiyyah, Winarso, \& Manfaat, 2019) yang meneliti kemampuan komunikasi matematika ditinjau dari perbedaan gender menyatakan bahwa subjek dengan gaya belajar converging memiliki kemampuan komunikasi matematika tinggi (baik).

\section{Mahasiswa dengan Gaya Belajar Acomodating}

Pada mahasiswa dengan gaya belajar acomodating, diambil subjek laki-laki dan perempuan dengan menganalisis permasalahan geometri pada soal nomor 5. Adapun jawaban dari subjek laki-laki dengan gaya belajar acomodating disajikan pada Gambar 7.

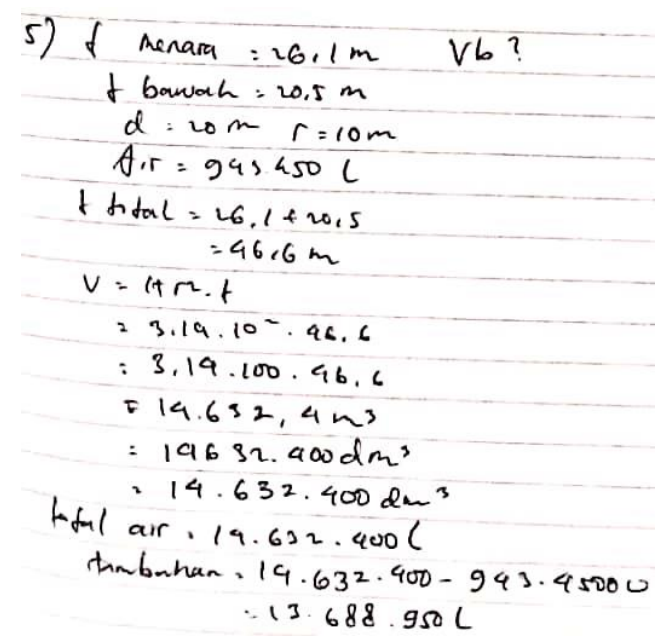

Gambar 7. Jawaban subjek laki-laki dengan gaya belajar accomodating

Berdasarkan hasil tertulis soal pemecahan masalah pada subjek lakilaki dengan gaya belajar accomodating, maka dapat dideskripsikan subjek tersebut dalam tahapan memahami masalah sudah dapat menuliskan 
dengan baik, terlihat bahwa subjek lakilaki dapat menuliskan informasi yang diketahui dan pertanyaan yang diajukan pada soal dengan benar. Pada tahapan menyusun rencana pemecahan masalah, subjek tersebut sudah cukup dalam tahapan ini yaitu dengan menuliskan volume tabung dan rumus menentukan tambahan air yang dibutuhkan pada bagunan menara air, tetapi belum dapat mengilustrasikan soal dalam gambar bangun ruang tabung. Pada tahapan melaksanakan rencana pemecahan masalah, subjek tersebut tidak dapat menyelesaikan dengan benar, kesalahannya terdapat pada tinggi dalam volume tabung yang seharusnya untuk tingginya didapatkan dari selisih antara tinggi bangunan dan tinggi tiang. Pada tahapan mengecek kembali hasil pemecahan masalah, subjek tersebut tidak menuliskan kesimpulan dari jawaban yang diperolehnya sehingga kurang dalam tahapan ini.

Hasil selanjutnya adalah jawaban dari subjek perempuan dengan gaya belajar accomodating yang disajikan pada Gambar 8.

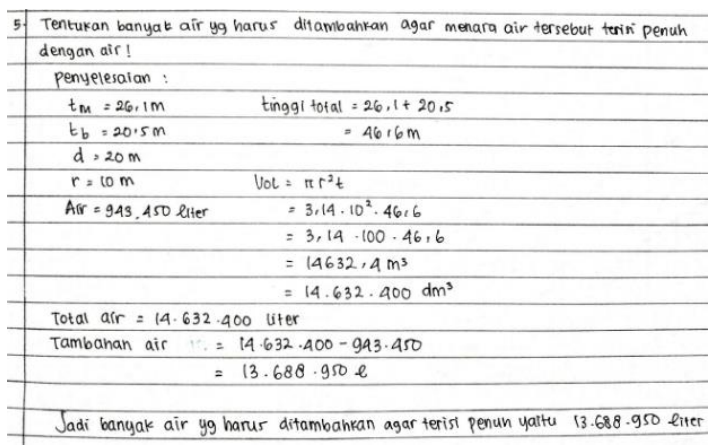

Gambar 8. Jawaban subjek perempuan dengan gaya belajar accomodating

Berdasarkan hasil tertulis soal pemecahan masalah pada subjek perempuan dengan gaya belajar accomodating, maka dapat dideskripsikan subjek tersebut dalam tahapan memahami masalah sudah dapat menuliskan dengan baik, terlihat bahwa subjek perempuan dapat menuliskan informasi yang diketahui dan pertanyaan yang diajukan pada soal dengan benar. Pada tahapan menyusun rencana pemecahan masalah, subjek tersebut sudah cukup dalam tahapan ini yaitu dengan menuliskan volume tabung dan rumus menentukan tambahan air yang dibutuhkan pada bagunan menara air, tetapi belum dapat mengilustrasikan soal dalam gambar bangun ruang tabung. Pada tahapan melaksanakan rencana pemecahan masalah, subjek tersebut tidak dapat menyelesaikan dengan benar. Pada tahapan mengecek kembali hasil pemecahan masalah, subjek tersebut tidak menuliskan kesimpulan dari jawaban yang diperolehnya sehingga kurang dalam tahapan ini.

Berdasarkan pemaparan di atas, maka dapat disimpulkan hasil tertulis subjek laki-laki dan perempuan dengan gaya belajar accomodating dalam Tabel 5.

Tabel 5. Rangkuman mahasiswa dengan gaya belajar accomodating

\begin{tabular}{lll}
\hline \multirow{2}{*}{ Tahapan } & \multicolumn{2}{l}{ Kategori } \\
\cline { 2 - 3 } & $\begin{array}{l}\text { Laki- } \\
\text { laki }\end{array}$ & Perempuan \\
\hline $\begin{array}{l}\text { Memahami } \\
\text { masalah }\end{array}$ & Baik & Baik \\
$\begin{array}{l}\text { Menyusun } \\
\text { rencana } \\
\text { pemecahan } \\
\text { masalah }\end{array}$ & Cukup & Cukup \\
$\begin{array}{l}\text { Melaksanakan } \\
\text { rencana } \\
\text { pemecahan } \\
\text { masalah }\end{array}$ & Cukup & Cukup \\
$\begin{array}{l}\text { Mengecek } \\
\text { kembali hasil } \\
\text { pemecahan } \\
\text { masalah }\end{array}$ & Kurang & Cukup \\
\hline
\end{tabular}


Pada tahapan memahami masalah, kedua subjek berada pada kategori baik. Kedua subjek lengkap dalam menguraikan permasalahan dan antusias untuk mencari penyelesaiannya. Hal ini sejalan dengan (Chasanah, Wicaksono, Nurtsaniyah, \& Utami, 2020) yang menyampaikan bahwa subjek dengan gaya belajar accomodating pada saat pembelajaran cenderung terfokus pada temannya, suka melihat pekerjaan temannya, tidak mudah menyerah pada saat mengerjakan soal. Pada tahapan menyusun rencana pemecahan masalah dan melaksanakan rencana pemecahan masalah, kedua subjek berada pada kategori cukup. Sedangkan pada tahapan mengecek kembali hasil pemecahan masalah, subjek laki-laki berada pada kategori kurang sedangkan subjek perempuan berada pada kategori cukup.

Berdasarkan keseluruhan jawaban subjek dengan gaya belajar accomodating, subjek laki-laki dan perempuan berada pada kategori cukup. Penelitian ini relevan dengan penelitian dari (Riau \& Junaedi, 2016) yang menyatakan bahwa subjek dengan gaya belajar accomodating mampu pada langkah melaksanakan pemecahan masalah tetapi tidak melakukan pengecekan kembali. Selain itu, (Fatkhiyyah, Winarso, \& Manfaat, 2019) yang meneliti kemampuan komunikasi matematika ditinjau dari perbedaan gender. Dalam penelitiannya, menyatakan bahwa subjek dengan gaya belajar accomodating memiliki kemampuan komunikasi matematika sedang (cukup).

\section{KESIMPULAN DAN SARAN}

Penelitian ini mendeskripsikan kemampuan mahasiswa dalam pemecahan masalah geometri berbasis budaya lokal ditinjau dari perbedaan gender dan gaya belajar mengalami perbedaan dalam tinjauan kemampuan individu baik pada laki-laki maupun perempuan. Kemampuan mahasiswa dengan gaya belajar diverging, subjek laki-laki berada pada kategori kurang dan subjek perempuan berada pada kategori cukup dalam pemecahan masalah. Kemampuan mahasiswa dengan gaya belajar assimilating, converging, dan accomodating baik subjek laki-laki maupun perempuan berada pada kategori cukup dalam pemecahan masalah.

Berdasarkan hasil penelitian mahasiswa dengan gaya belajar diverging perlu diberikan kekuatan dalam mengamati dalam pemecahan masalah. Subjek laki-laki masih berada pada kategori kurang sehingga perlu penelitian lebih lanjut dalam meningkatkan kemampuan pemecahan masalah. Perlakuan terhadap subjek sesuai gaya belajar dalam pendekatan pada situasi pembelajaran perlu disesuaikan dengan berbagai metode.

\section{DAFTAR PUSTAKA}

Bire, A. L., Geradus, U., \& Bire, J. (2014). Pengaruh Gaya Belajar Visual, Auditorial, dan Kinestetik Terhadap Prestasi Belajar Siswa. Jurnal Kependidikan, 44(2), 168174.

Budiarto, M. T., \& Artiono, R. (2019). Geometri dan Permasalahan dalam Pembelajarannya (Suatu Penelitian Meta Analisis). JUMADIKA Jurnal Magister Pendidikan Matematika, 1(1), 918.

Chao, J. Y., Tzeng, P. W., \& Po, H. Y. (2017). The Study of Problem Solving Process of E-book PBL Course of Atayal Senior High School Students in Taiwan. EURASIA Journal of Mathematics 
DOI: https://doi.org/10.24127/ajpm.v10i1.3256

Science and Technology Education, 13(3), 1001-1012.

Chasanah, A. N., Wicaksono, A. B., Nurtsaniyah, S., \& Utami, R. N. (2020). Analisis Kemampuan Literasi Matematika Mahasiswa pada Mata Kuliah Statistika Inferensial Ditinjau dari Gaya Belajar. Edumatica : Jurnal Pendidikan Matematika, 10(2), 45-56.

Fatkhiyyah, I., Winarso, W., \& Manfaat, B. (2019). Kemampuan Komunikasi Matematika Siswa Ditinjau dari Perbedaan Gaya Belajar Menurut David Kolb. Jurnal Elemen, 5(2), 93-107.

Jalinus, N., Ganefri, Syahril, Wulansari, R. E., Nabawi, R. A., Yunos, J. M., \& Kiong, T. T. (2020). Comparison of Learning Style between Engineering and NonEngineering Students in Vocational Education. International Journal of Innovation, Creativity and Change, 13(12), 283-294.

Kolb, A. Y., \& Kolb, D. A. (2017). Learning Styles and Learning Spaces: Enhancing Experiential Learning in Higher Education. Academy of Management Learning \& Education, 4(2), 193212.

Ma, V. J., \& Ma, X. (2014). A Comparative Analysis of the Relationship between Learning Styles and Mathematics Performance. International Journal of STEM Education, 1(3), 1-13.

Mawaddah, S., \& Anisah, H. (2015). Kemampuan Pemecahan Masalah Matematis Siswa pada Pembelajaran Matematika dengan Menggunakan Pembelajaran Model Generatif
(Generative Learning) di SMP. EDU-MAT: Jurnal Pendidikan Matematika, 3(2), 166-175.

Middleton, K., Ricks, E., Wright, P., \& Grant, S. (2013). Examining the Relationship Between Learning Style Preferences and Attitudes Toward Mathematics Among Students in Higher Education. Institute for Learning Styles Journal, 1(3), 1-15.

Miles, M. B., \& Huberman, A. M. (1994). Qualitative Data Analysis: An Expanded Sourcebook. London: SAGE Publications Ltd.

NCTM. (2000). Principles and Standards for School Mathematics. Reston VA: National Council of Teachers of Mathematics Inc.

Polya, G. (2014). How to Solve It: A New Aspect of Mathematical Method. New Jersey: Princeton University Press.

Riau, B. E., \& Junaedi, I. (2016). Analisis Kemampuan Pemecahan Masalah Matematik Siswa Kelas VII Berdasarkan Gaya Belajar pada Pembelajaran PBL. Unnes Journal of Mathematics Education Research, 5(2), 166178.

Sengodan, V., \& Iksan, Z. H. (2012). Students' Learning Styles and Intrinsic Motivation in Learning Mathematics. Asian Social Science, 8(16), 17-23.

Zulfiani, Suwarna, I. P., \& Sumantri, M. F. (2020). Science Adaptive Assessment Tool: Kolb's Learning Style Profile and Student's Higher Order Thinking Skill Level. Jurnal Pendidikan IPA Indonesia, 9(2), 194-207. 